\title{
PENGELOLAAN SAMPAH BERBASIS MASYARAKAT DI DESA PAKRAMAN PADANGTEGAL KECAMATAN UBUD KABUPATEN GIANYAR
}

\author{
I Putu Juniartha ${ }^{1 *}$, Made Antara ${ }^{2)}$, Made Sudarma ${ }^{3)}$ \\ 1) Magister Ilmu Lingkungan Universitas Udayana \\ 2) Program Studi Agribisnis, Fakultas Pertanian Universitas Udayana \\ ${ }^{3}$ ) Pusat Penelitian Lingkungan Hidup Universitas Udayana \\ *Email: Juniartha62@yahoo.com
}

\begin{abstract}
COMMUNITY BASED WASTE MANAGEMENT IN THE VILLAGE OF PADANGTEGAL PAKRAMAN KECAMATAN UBUD, GIANYAR DISTRICT
\end{abstract}

The results of this study indicate: (1) Characteristics of waste in Pakraman Padangtegal Village consisted of $83.88 \%$ organic waste, $7.24 \%$ plastic waste, $4.42 \%$ paper waste, $2.22 \%$ bottle waste, glass waste at $1.28 \%$ and metal waste at $0.96 \%$; (2) public perception in waste management in Pakraman Village, Padangtegal that most of the people in Pakraman Village, Padangtegal, already know about the definition of waste and the danger of waste if it is not managed properly. Besides that the community also knows the difference between organic and inorganic waste so that the process of sorting waste in the place provided can run well, and the community's perception of waste management services has gone well with the transportation of waste twice a day; (3) the participation of the Pakraman Padangtegal Village community in waste management has played a role in various stages of waste management, starting from the sorting, garbage collection and garbage disposal, which complies with waste regulations and maintains the quality of the environment in Padangtegal Pakraman Village. The participation of the tourism industry in the process of waste management in Pakraman Village, Padangtegal, can be seen as being involved in the process of sorting waste and paying monthly fees and waste fees. The community participation in the waste management process is to help the government to socialize the waste management process by carrying out waste collection activities every week and provide a place for the waste management process. Suggestions in this study are that waste managers will immediately add facilities and infrastructure for waste transportation and accelerate the expansion of waste management in the village of Pakraman Padangtegal.

Keywords: Waste Management System, Pakraman Village

\section{PENDAHULUAN}

Desa Pakraman Padangtegal merupakan salah satu desa pakraman yang berada di Kecamatan Ubud, Kabupaten Gianyar, Provinsi Bali yang sumber perekonomiannya sebagian besar bertumpu pada sektor pariwisata. Perkembangan Desa Padangtegal sebagai daerah pariwisata menyebabkan terjadinya peningkatan pembangunan fisik dari industri pendukung pariwisata yang terkonsentrasi di daerah seperti: villa, restoran, art shop dan lain-lain. Meningkatnya pembangunan tersebut diikuti pula dengan semakin meningkatnya jumlah penduduk dan perkembangan pembangunan tersebut tidak disertai dengan sarana dan prasarana serta jaringan infrastruktur yang memadai. Desa Padangtegal yang merupakan kawasan dengan tingkat perkembangan yang cukup pesat telah terjadi permasalahanpermasalahan lingkungan, dimana salah satunya adalah permasalahan sampah. 
Masalah sampah adalah salah satu dampak negatif dari perkembangan pariwisata yang dapat merusak sumber daya alam dan budidaya apabila tidak ditangani secara serius, dan terdapat pula hubungan antara kebersihan dengan hunian hotel/kedatangan wisatawan ke Bali. Untuk mengatasi hal tersebut diperlukan usaha untuk mengurangi masalah tersebut dengan melibatkan partisipasi masyarakat. Peran aktif dari masyarakat sangat dibutuhkan khususnya daerah pariwisata agar sampah dapat dikelola dengan baik sehingga daerah tujuan wisata dapat terhindar dari sampah. Contoh kasus seperti penyakit SARS, Flu Burung, Demam Berdarah dan Malaria yang pernah terjadi di Indonesia cukup mempengaruhi arus kedatangan wisatawan. Beberapa negara seperti Australia, Jepang, Korea dan lain-lain mengeluarkan travel warning kepada warganya supaya mengurangi atau menghindari kunjungan ke Indonesia sehingga hal tersebut mengakibatkan terjadinya penurunan jumlah kunjungan wisatawan ke Bali pada periode tahun 2002 dan 2003 sebesar $5,23 \%$ dan $22,77 \%$ (Diparda, 2006).

Permasalah sampah disebabkan oleh beberapa faktor yaitu pertambahan penduduk, perubahan pola konsumsi dan gaya hidup masyarakat yang akan meningkatkan jumlah timbulan sampah, jenis dan keberagaman karakteristik sampah. Meningkatnya daya beli masyarakat terhadap berbagai jenis bahan pokok dan hasil teknologi serta meningkatnya usaha atau kegiatan penunjang pertumbuhan ekonomi suatu daerah juga memberikan kontribusi yang besar terhadap kuantitas dan kualitas sampah yang dihasilkan (Suarna, 2008). Di samping itu masalah persampahan menjadi bagian penting untuk dianalisis karena menyangkut isu-isu lingkungan yang vital terutama di kawasan pariwisata yang menghendaki kualitas lingkungan yang prima. Permasalah sampah juga sangat terkait dengan tingkat pemanfaatan lahan dan kemampuan wilayah tersebut menyediakan fasilitas pengelolaan sampah sehingga sampah tidak menjadi masalah lingkungan.

Pengelolaan Sampah Berbasis

Masyarakat (PSBM) di Desa Pakraman Padangtegal, erat kaitannya dengan keberadaan tempat pengolahan sampah terpadu (TPST). Tujuan awal pembangunan TPST tersebut adalah memberikan edukasi kepada warga tentang berbagai metode pengelolaan sampah, pentingnya menanam dan sekaligus bahaya penanganan sampah yang tidak tepat. Selain itu pembangunan TPST bertujuan sebagai penyediaan sarana pengelolaan sampah skala kawasan di Kecamatan Ubud. Perkembangan pengelolaan sampah di Desa Padangtegal bertujuan agar menciptakan desa yang bersih, hijau dan sebagai percontohan dalam pengelolaan sampah. Untuk kelancaran dari tujuan pengelolaan yang terdapat di kawasan tersebut sangat dibutuhkan peranan masyarakat agar proses pengelolaan sampah berjalan dengan baik. Seperti yang ada saat ini pada kawasan ini sudah didirikan rumah kompos yang bertujuan untuk pemilahan sampah yang berasal dari pemukiman warga. Rumah kompos dipandang perlu untuk alternatif pemilahan jenis sampah organik, sedangkan sampah anorganik akan di daur ulang menjadi barang-barang yang lebih berguna untuk mendapatkan hasil ekonomi. Sementara itu sampah dengan golongan lebih banyak akan di bawa ke tempat pengolahan akhir yang berada di Temesi, Gianyar.

Menurut Suarna (2008), berbagai masalah juga dihadapi dalam pengelolaan sampah berbasis masyarakat atau komunitas pada pemukiman kota yang juga sebagai daerah pariwisata termasuk Desa Pakraman Padangtegal, di antaranya ada masalah pengadaan lahan untuk lokasi depo, terbatasnya peralatan teknologi dan perawatannya, terbatasnya dana untuk perekrutan tenaga kerja baru, produksi kompos yang masih rendah dan terbatasnya pemasaran kompos. Untuk itu model pengelolaan sampah berbasis sosial kemasyarakatan dapat dilakukan secara adaptif dengan memperhatikan aspek karakteristik sosial dan budaya masyarakat, aspek ruang (lingkungan), volume dan jenis sampah yang dihasilkan. Pola pengelolaan sampah berbasis masyarakat sebaiknya dilakukan secara sinergi (terpadu) dari berbagai elemen (desa, pemerintah, LSM, pengusaha/swasta,sekolah dan komponen lain yang terkait) dengan menjadikan masyarakat 
lokal sebagai objek dan subjek pembangunan, khususnya dalam pengelolaan sampah untuk menciptakan lingkungan bersih, aman, sehat, asri dan lestari.

\section{METODOLOGI}

\subsection{Lokasi Penelitian}

Penelitian ini dilakukan di Desa Pakraman Padangtegal, Kecamatan Ubud, Kabupaten Gianyar.

\subsection{Ruang Lingkup Penelitian}

Adapun ruang lingkup dalam penelitian ini adalah sebagai berikut:

1) Mengidentifikasi volume dan karakteristik sampah di Desa Pakraman Padangtegal.

2) Menganalisis persepsi rumah tangga tentang pengelolaan sampah di Desa Pakraman Padangtegal.

3) Mengidentifikasi peran serta masyarakat Desa Pakraman Padangtegal, industri pariwisata dan komunitas pengelolaan sampah di Desa Pakraman Padangtegal.

\subsection{Penentuan Sumber Data}

Data diperoleh dengan melakukan observasi, penyebaran kuesioner dan wawancara ke wilayah penelitian yaitu Desa Pakraman Padangtegal.

\subsection{Analisis Data}

Data dianalisis dengan analisis deksriptif yang bermaksud mendeskripsikan fenomena yang terjadi berdasarkan hasil eksplorasi pengelolaan sampah berbasis masyarakat di Desa Pakraman Padangtegal.

\section{HASIL DAN PEMBAHASAN}

\subsection{Volume dan Karakteristik Sampah}

Karakteristik sampah yang terangkut oleh jasa pelayanan pengangkutan sampah Desa Pakraman Padangtegal terdiri atas sampah organik dengan persentase $83,91 \%$, plastik 7,24\%, kertas 4,42 \%, botol 2,18\%, kaca $1,28 \%$ dan logam $0,97 \%$. Sampah organik yang terangkut oleh jasa pelayanan pengangkutan sampah Desa Pakraman Padangtegal berupa sampah sapuan halaman maupun kebun, dimana sampah sapuan halaman berasal dari pemukiman penduduk, hotel, villa yang berada di kawasan Desa Pakraman Padangtegal, dan termasuk juga sampah kebun yang berasal dari hotel, villa yang berada di daerah Desa Padangtegal yang berupa daun-daunan dan sisa-sisa tumbuhan. Faktor yang menentukan kehadiran sampah anorganik dalam timbunan sampah selain faktor budaya masyarakat juga ditentukan oleh perlakuan awal terhadap sampah tersebut (Atmaja, 2004). Perlakuan tersebut adalah aktivitas yang terjadi sejak sampah dihasilkan sampai sampah terangkut ke TPS, seperti aktivitas pemilahan sampah organik dan anorganik dari sumbernya yang dilakukan oleh masyarakat atau industri pariwisata serta petugas pengangkut sampah. Hal tersebut merupakan penyebab kehadiran sampah anorganik (plastik, kertas, botol, kaca, logam) dalam timbunan sampah yang relatif besar. Gambar 1 menunjukkan karakteristik sampah yang terangkut oleh jasa pelayanan pengangkutan sampah di Desa Pakraman Padangtegal. 


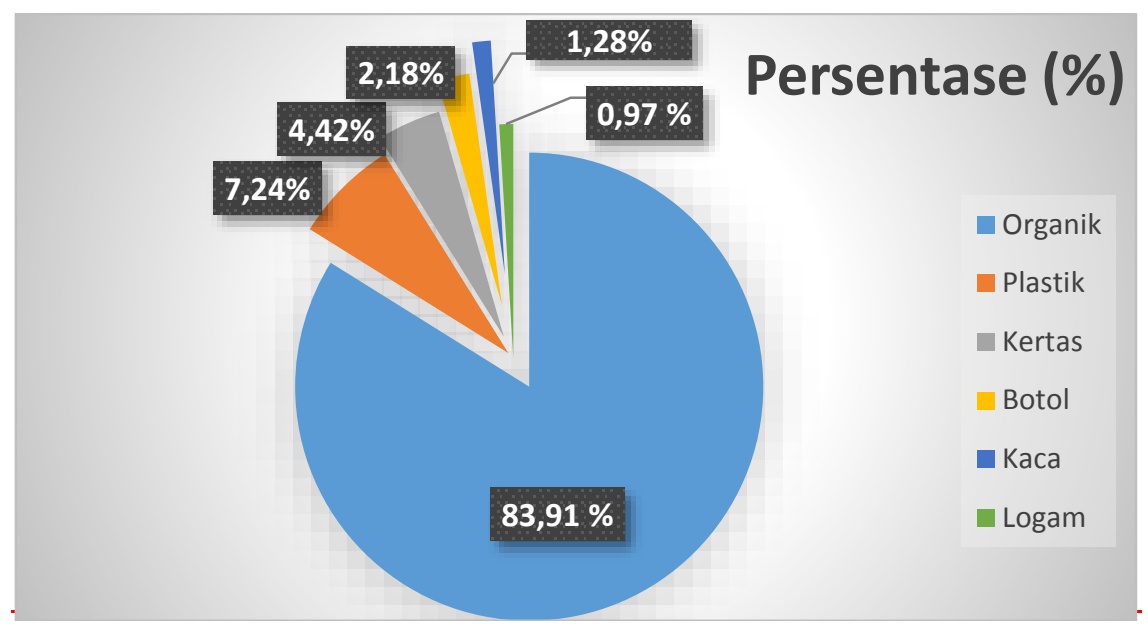

Gambar 1

Persentase Karakteristik Sampah yang Terangkut oleh

Jasa Pelayanan Pengangkutan Sampah Desa Pakraman Padangtegal

\subsection{Persepsi Rumah Tangga Tentang Pengelolaan Sampah di Desa Pakraman Padangtegal}

Berdasarkan hasil penelitian diperoleh jawaban yang beragam mengenai pengertian dari sampah. Sebagian besar (100\%) responden mengatakan bahwa yang dimaksud dengan sampah adalah sesuatu yang tidak dipergunakan lagi yang diperoleh dari aktivitas manusia dan lingkungan serta perlu penanganan yang khusus untuk mengatasi permasalahan sampah. Sampah jika tidak segera ditangani akan banyak menimbulkan efek negatif seperti timbulnya berbagai penyakit, menimbulkan bau yang tidak sedap, merusak pemandangan dan mengganggu aktivitas pariwisata di Desa Pakraman Padangtegal. Penilaian masyarakat pada permasalahan sampah adalah dengan mengatasi permasalahan sampah tersebut secara bersama-sama meliputi masyarakat itu sendiri, pihak pengelola, pemerintah dan juga bekerja sama dengan industri pariwisata di wilayah tersebut serta peran komunitas pengelola sampah.

Berdasarkan hasil penelitian sebagian besar (95\%) juga sudah mengetahui pengertian dari sampah organik dan sampah anorganik. Pengertian yang diberikan oleh responden mengenai sampah organik adalah sampah yang berasal dari sisa-sisa makanan dan sisa daun-daunan dari tumbuhan yang dapat dimanfaatkan untuk pembuatan pupuk kompos untuk kesuburan tanah, sedangkan untuk sampah anorganik responden memberikan pengertian sampah yang berasal dari bahan plastik, botol, kaleng, kertas yang dapat bermanfaat melalui proses daur ulang untuk dijadikan barang kerajinan. Sekitar $5 \%$ responden tidak memberikan jawaban mengenai pengertian sampah organik dan anorganik dengan alasan tidak tahu.

Pelayanan pengelolaan sampah di masing-masing banjar menurut penilaian responden sudah baik. Hal ini dibuktikan dari ketepatan waktu pengangkutan sampah oleh petugas kebersihan yaitu dua kali dalam sehari dan diperlukan kerjasama yang baik dengan masyarakat sehingga pelayanan dalam penanganan sampah dapat berjalan dengan maksimal. Pelayanan pengangkutan sampah dilakukan oleh Desa Pakraman Padangtegal dengan mendirikan rumah kompos untuk solusi dalam pengelolaan sampah. Dengan adanya rumah kompos sebagai jasa pelayanan pengangkutan sampah responden mengharapkan Desa Pakraman Padangtegal memiliki citra yang baik disamping dari aktivitas pariwisata yang tinggi juga menjadi daerah yang mengelola sampah secara mandiri. Dengan memiliki fasilitas pengelolaan sampah secara mandiri, desa bisa memanfaatkan dan mengambil keuntungan dari pengelolaan tersebut, misalnya dengan mengelola bahan daur ulang yang terbuang menjadi kompos untuk kepentingan hutan desa (Monkey Forest). Langkah ini akan mengurangi beban pemerintah, sekaligus memberikan gambaran positif sebagai 
destinasi pariwisata, bahwa Desa Pakraman Padangtegal memiliki komitmen menjaga kelestarian alam.

\subsection{Peran serta Masyarakat Desa Pakraman Padangtegal, Industri Pariwisata dan Komunitas Pengelola Sampah dalam Pengelolaan Sampah di Desa Pakraman Padangtegal}

\subsubsection{Peran serta Masyarakat Desa Pakraman Padangtegal dalam Pengelolaan Sampah di Desa Pakraman Padangtegal}

A. Pewadahan Sampah

Dari hasil penelitian dapat dilihat bahwa sebanyak $50 \quad \%$ responden menyediakan tempat penampungan sampah di rumahnya. Waktu sampah penuh pada tempat sampah di rumah sebanyak $15 \%$ responden mengatakan tempat penampungan sampah penuh kurang dari sehari, sebanyak $25 \%$ responden mengatakan tempat penampungan sampah penuh dalam sehari dan sebanyak 10 $\%$ responden mengatakan tempat penampungan sampah penuh lebih dari sehari. Gambar 2 menunjukkan peranserta masyarakat dalam pewadahan sampah

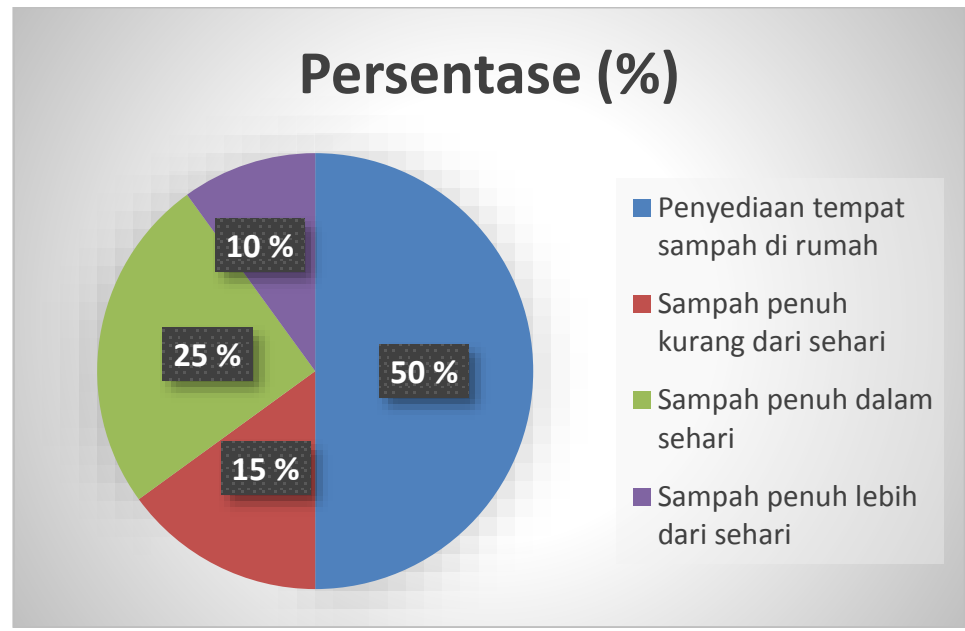

Gambar 2

Peranserta Masyarakat Desa Pakraman Padangtegal dalam Pewadahan Sampah

\section{B. Pembuangan sampah}

Dari hasil penelitian menunjukkan bahwa sekitar $45 \%$ responden menyatakan sepenuhnya dibuang pada tempat sampah, sebanyak $35 \%$ responden menyatakan sampah dibuang sebagian besar pada tempat sampah dan sebanyak $5 \%$ responden mengatakan sampah dibuang sebagian kecil. Sampah jika tidak sepenuhnya dibuang pada tempat sampah didapatkan sebanyak $5 \%$ responden menyatakan dimanfaatkan kembali dan sebanyak $2 \%$ responden menyatakan sampah dikelola. Ketika tempat pembuangan sampah yang disediakan pemerintah penuh sebanyak $5 \%$ responden mengatakan sampah akan ditampung sementara dirumah dan sebanyak $3 \%$ responden menyatakan sampah akan ditaruh diluar tempat penampungan sampah sementara (TPS) yang penuh. Gambar 3 menunjukkan peranserta masyarakat dalam pembuangan sampah. 


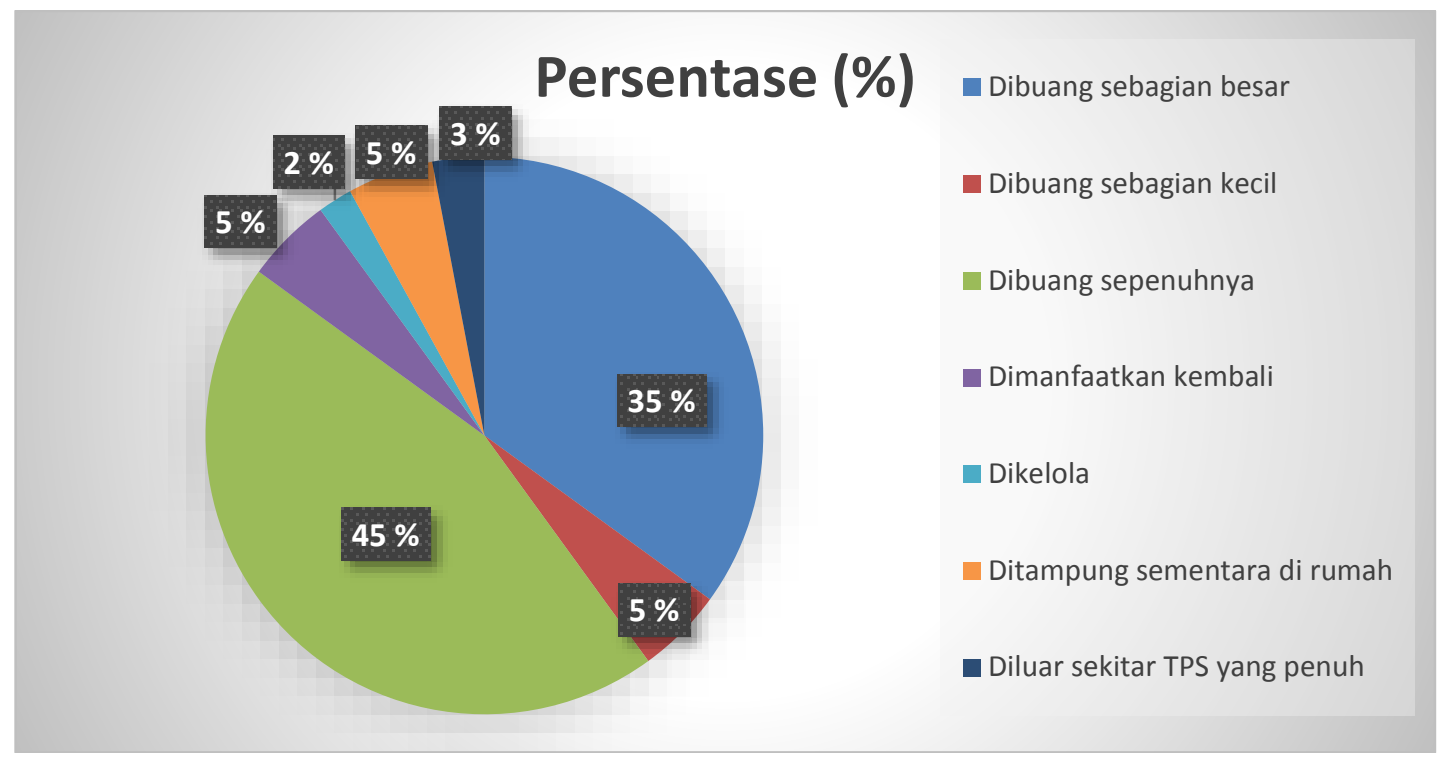

Gambar 3

Peranserta Masyarakat Desa Pakraman Padangtegal dalam Pembuangan Sampah

\section{Pemilahan sampah}

Dari hasil penelitian menunjukkan bahwa responden yang bersedia melakukan pemilahan sampah sebanyak $78 \%$, bersedia apabila tidak ada halangan sebanyak $18 \%$ dan dan $2 \%$ mengatakan kurang tahu dan tidak bersedia dalam pemilahan sampah. Jenis sampah yang dipilah oleh responden adalah sampah organik sebanyak $78 \%$ dan sampah anorganik sebanyak $22 \%$. Sedangkan perlakuan responden terhadap sampah yang dipilah tersebut adalah sebanyak $82 \%$ mengatakan dimanfaatkan untuk dijadikan kompos dan $18 \%$ mengatakan dijual. Masih adanyak responden yang tidak melakukan pemilahan sampah karena mereka tidak mengetahui apakah ada gunanya sampah yang dibuang dan dipisahkan, karena pada akhirnya saat pengangkutan sampah yang dibuang akan bercampur kembali. Responden juga mengatakan tidak memiliki waktu untuk memisahkan sampahnya dan juga karena malas untuk mengerjakannya. Gambar 4 menunjukkan pemilahan atau pemisahan sampah oleh masyarakat, Gambar 5 menunjukkan jenis sampah yang dipilah dan Gambar 6 menunjukkan perlakuan terhadap sampah yang dipilah.

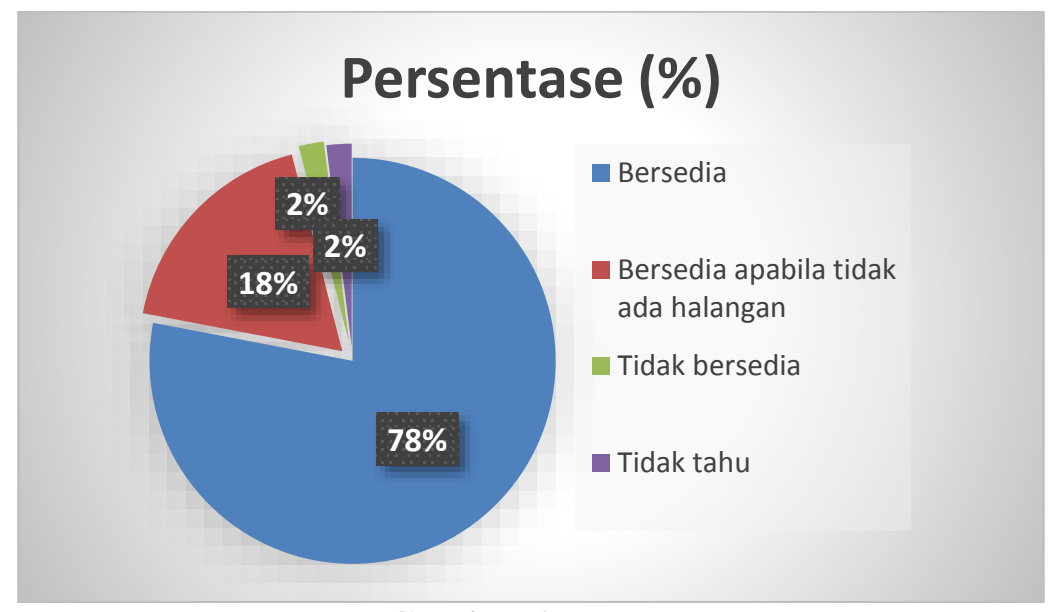

Gambar 4

Pemilahan atau Pemisahan Sampah oleh Masyarakat Desa Pakraman Padangtegal 


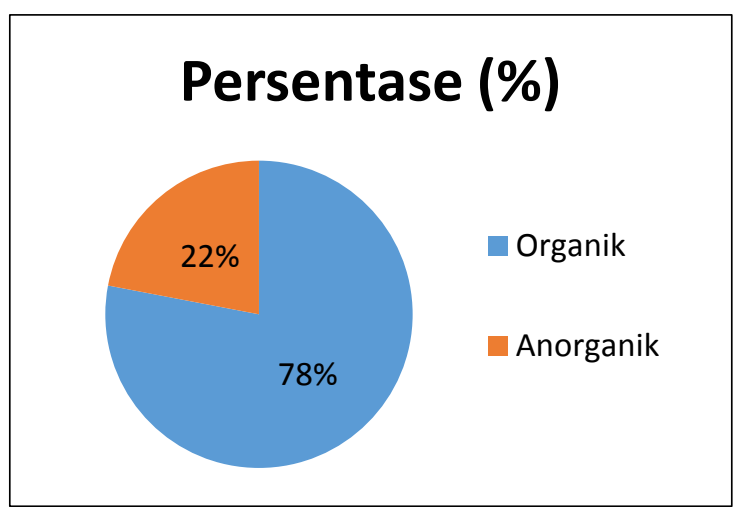

Gambar 5

Jenis Sampah yang Dipilah

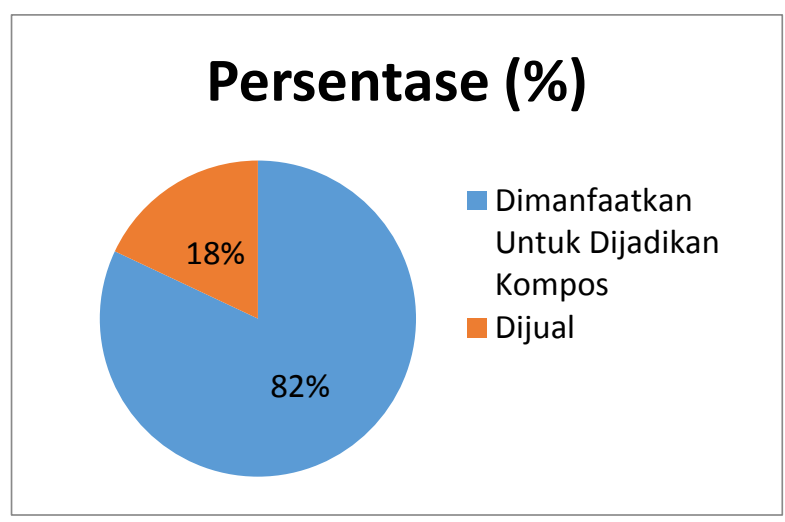

Gambar 6

Perlakuan Terhadap Sampah Organik yang Dipilah

\section{Peraturan Persampahan}

Hasil penelitian menunjukkan bahwa sebagian besar masyarakat sudah mengetahui mengenai peraturan persampahan sebanyak $95 \%$ dan masyarakat yang tidak mengetahui adanya peraturan persampahan sebanyak $5 \%$. Banyaknya masyarakat yang sudah mengetahui peraturan persampahan karena pemerintah sudah memberikan pengarahan dalam bentuk sosialisasi di masing-masing Desa/Banjar. Dalam peraturan persampahan yang terdapat di Desa Pakraman Padangtegal juga dilengkapi dengan adanya sanksi yang diberikan oleh pemerintah setempat jika terdapat masyarakat yang melanggar peraturan tersebut. Gambar 7 menunjukkan peranserta masyarakat dalam peraturan persampahan.

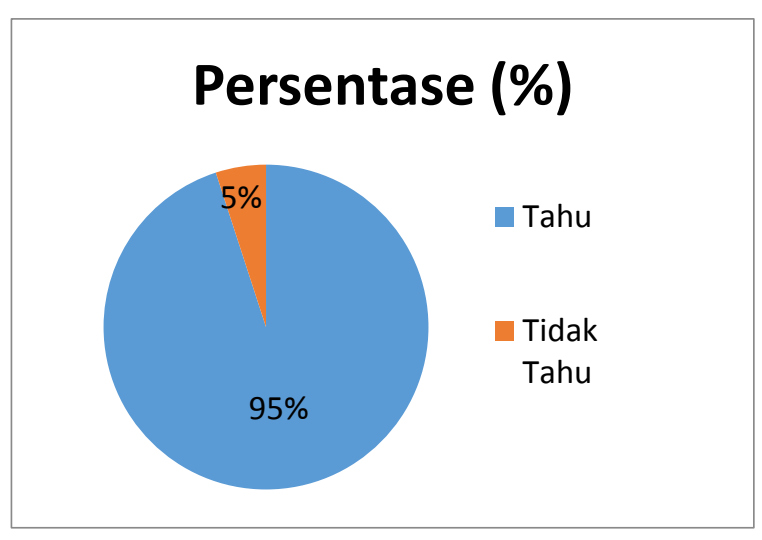

Gambar 7

Peran serta Masyarakat Desa Pakraman Padangtegal dalam Peraturan Persampahan

E. Peran serta Masyarakat dalam Menjaga Lingkungan

Peranserta masyarakat dalam menjaga lingkungan saat ini adalah melakukan kerja bakti baik secara mandiri ataupun kelompok. Hasil penelitianmenunjukkan kemauan masyarakat Desa Pakraman Padangtegal dalam menjaga lingkungan sekitar di Desa Pakraman Padangtegal ditunjukkan pada gambar 8.Sebagian besar yaitu $62 \%$ responden mengatakan bersedia melakukan kerja bakti, $31 \%$ responden bersedia melakukan kerja bakti apabila tidak ada halangan dan $7 \%$ responden tidak bersedia melakukan kerja bakti.

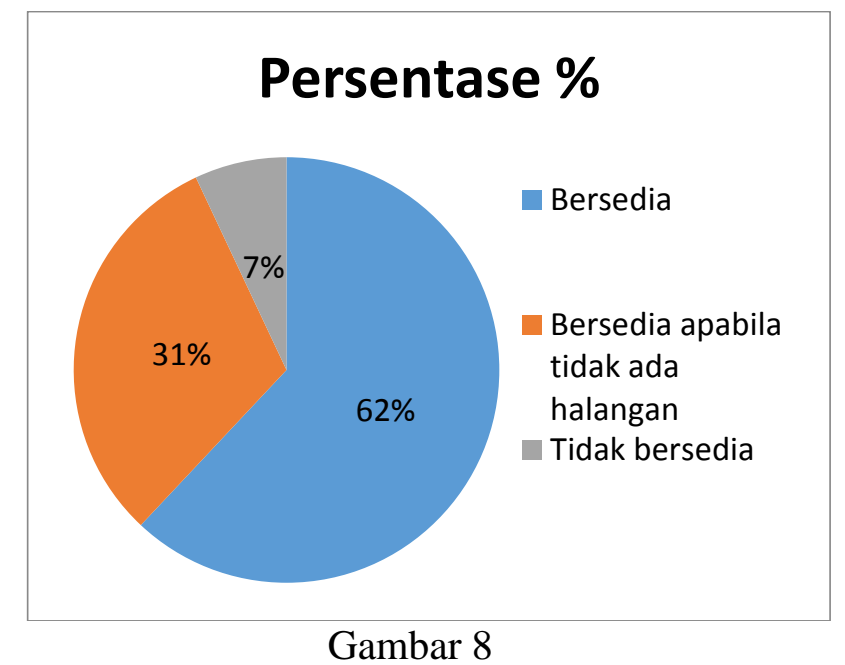

Ketersediaan masyarakat Desa Pakraman Padangtegal mengikuti kerja bakti 


\subsubsection{Peran Serta Industri Pariwisata dalam Pengelolaan Sampah di Desa Pakraman Padangtegal}

Dari hasil wawancara ke pihak pengelola sampah yang terdapat di Desa Pakraman Padangtegal didapatkan data bahwa peran serta industri pariwisata seperti hotel, villa, restoran, art shop dan toko di Desa Pakraman Padangtegal sangat membantu dalam proses pengelolaan sampah. Secara umum mereka mengetahui definisi tentang sampah yang merupakan barang yang tidak dapat dipakai lagi dan juga bisa dimanfaatkan kembali bila diolah dengan baik. Sampah yang dapat dimanfaatkan menurut responden tergolong sampah organik yang nantinya dapat di daur ulang menjadi pupuk kompos, sedangkan yang dapat dimanfaatkan tergolong anorganik yang nantinya bisa diolah menjadi berbagai kerajinan dan hiasan untuk mempercantik sudut ruangan disekitar industri. Disamping itu industri pariwisata yang ada di Desa Pakraman Padangtegal ikut dalam proses pemilahan sampah yang tergolong ke dalam sampah organik dan anorganik. Pemilahan sampah yang dilakukan bertujuan untuk mempermudah dalam pengangkutan sampah.

Menurut industri pariwisata sistem pengelolaan sampah di Desa Pakraman Padangtegal sudah berjalan dengan baik, hal itu dibuktikan oleh pengangkutan oleh petugas pengangkut sampah yang diangkut setiap dua kali dalam satu hari. Disamping itu untuk memudahkan petugas dalam mengangkut sampah tersebut pihak industri pariwisata membantu dalam sistem pengelolaan sampah dengan melakukan pemilahan antara sampah organik dan sampah anorganik. Pihak industri pariwisata juga membayar iuran untuk proses pengelolaan sampah sebesar Rp. 50.000 sampai Rp. 2.000.000 setiap bulannya. Dengan adanya kerjasama antara pemerintah, masyarakat dan bantuan dari pihak industri pariwisata menjadikan proses pengelolaan sampah di Desa Pakraman Padangtegal bisa lebih optimal dan terlaksana dengan baik.

\subsubsection{Peran Serta Komunitas Pengelola Sampah dalam Pengelolaan Sampah di Desa Pakraman Padangtegal}

Sampah merupakan bahan buangan yang dihasilkan dari aktivitas manusia maupun proses alam. Sampah dapat menjadi sumber penyakit jika tidak dikelola dengan baik. Pengelolaan sampah berbasis masyarakat Desa Pakraman Padangtegal sangat membantu pemerintah daerah dalam menciptakan kebersihan lingkungan yang sehat berdasarkan prinsip dan tujuan pelestarian lingkungan. Peran komunitas pengelola sampah dalam pengelolaan sampah dilakukan melalui sosialisasi dan kebiasaan hidup sehat serta kerjasama dengan pengepul untuk menjual sampah non organik dan melakukan daur ulang sampah yang dapat membantu pemerintah setempat.

Desa Pakraman Padangtegal memiliki rumah kompos sebagai tempat penampung dan pengelolaan sampah. Dari hasil wawancara yang dilakukan, rumah kompos juga bekerja sama dengan Trash Hero Ubud yang rutin mengadakan acara memungut bahan daur ulang non organik di area sekitar Ubud. Acara yang diselenggarakan setiap hari sabtu sore mulai dari pukul 17.00 sampai 18.00 WITA ini mendapatkan banyak antusias dari wisatawan manca negara yang ikut serta berpartisipasi. Rumah Kompos Padangtegal juga turut mengundang anakanak SD di Kecamatan Ubud untuk ikut berpartisipasi dan mengenalkan anak-anak akan bahayanya bahan daur ulang non organik.Kendala yang dihadapi adalah menyadarkan masyarakat setempat tentang bahaya sampah dan mengajak seluruh stakeholder untuk ikut berperan dalam proses pengelolaan sampah.

Dengan adanya kegiatan yang dilakukan oleh komunitas pengelola sampah diharapkan banyak masyarakat untuk ikut terlibat dalam proses pengelolaan sampah.. Peran komunitas dipandang perlu untuk dilibatkan disamping dapat membantu pemerintah dalam strategti pengelolaan sampah, komunitas tersebut juga langsung memberikan sosialisasi tentang bagimana pentingnya proses pengelolaan sampah serta memberikan wadah/tempat 
dalam proses pengelolaan sampah yang terpadu.

\section{SIMPULAN DAN SARAN}

\subsection{Simpulan}

1. Karakteristik sampah di Desa Pakraman Padangtegal terdiri atas sampah organik sebesar $83,88 \%$, sampah plastik sebesar 7,24 \%, sampah kertas sebesar 4,42\%, sampah botol sebesar $2,18 \%$, sampah kaca sebesar $1,28 \%$ dan sampah logam sebesar 0,97\%.

2. Persepsi rumah tangga tentang pengelolaan sampah di Desa Pakraman Padangtegal bahwa sebagian besar masyarakat yang ada di Desa Pakraman Padangtegal sudah mengetahui tentang definisi sampah dan bahaya sampah jika tidak dikelola dengan baik. Disamping itu masyarakat juga mengetahui perbedaan antara sampah organik dan anorganik supaya dalam proses pemilahan sampah pada tempat yang disediakan dapat berjalan dengan baik, serta persepsi masyarakat tentang jasa pengelolaan sampah sudah berjalan dengan baik dengan pengangkutan sampah dua kali dalam sehari dan dengan didirikannya rumah kompos sebagai alternatif pengelolaan sampah agar berjalan secara maksimal.

3. Peranserta masyarakat Desa Pakraman Padangtegal dalam pengelolaan sampah sudah berperan dalam berbagai tahap pengelolaan sampah yaitu mulai dari tahap pemilahan, pewadahan sampah dan pembuangan sampah yang mematuhi peraturan persampahan serta menjaga kualitas lingkungan di wilayah Desa Pakraman Padangtegal. Peranserta industri pariwisata dalam proses pengelolaan sampah di Desa Pakraman Padangtegal dapat dilihat keterlibatnya dalam proses pemilahan sampah sehingga memudahkan petugas untuk mengangkut sampah yang sudah dipilah, serta kesediaan membayar retribusi dan iuran sampah setiap bulannya untuk kesejahteraan tempat pengelolaan sampah di daerah tersebut. Adapun peranserta komunitas dalam proses pengelolaan sampah adalah ikut membantu pemerintah untuk mensosialisasikan tentang proses pengelolaan sampah dengan melakukan kegiatan pemungutan sampah setiap minggunya serta menyediakan tempat untuk proses pengelolaan sampah.

\subsection{Saran}

1. Pemerintah perlu memberikan contoh pada masyarakat mulai dari pemilahan sampah di setiap kantorkantor, dengan membuat perlombaan Kantor Pemerintah Sadar Lingkungan. Bukan hanya mencari kabupaten terbaik tapi mampu menjadi contoh bagi warganya.

2. Pengelola sampah di Desa Pakraman Padangtegal perlu meningkatkan sarana dan prasarana dalam pengelolaan sampah seperti penambahan armada angkut untuk pengambilan di gang-gang sehingga dapat memaksimalkan pelayanan kepada masyarakat.

3. Pengelola sampah di Desa Pakraman Padangtegal diharapkan mempercepat perluasan tempat daur ulang sampah organik sehingga proses pengelolaannya bisa berjalan lebih maksimal dan dapat dihasilkan lebih banyak pupuk kompos yang nantinya bisa dimanfaatkan atau dijual.

4. Adapun saran untuk studi lanjutan dalam pengelolaan sampah berbasis masyarakat agar dapat melengkapi dan menambahkan kekurangankekurangan dari penelitian sebelumnya agar menghasilkan pengelolaan sampah yang lebih baik, yaitu :

a. Perluasan wilayah penelitian menjadi seluruh Kecamatan Ubud

b. Mengkaji tentang aspek pembiayaan dan operasional pengangkutan guna mendukung pengelolaan sampah berkelanjutan. 


\section{DAFTAR PUSTAKA}

Amirin, T., 2011, Populasi Dan Sampel Penelitian 4 : Ukuran Sampel Rumus Slovin, Erlangga, Jakarta.

Atmaja P, I.B.Gede. 2004. Studi Karakteristik dan Potensi Daur Ulang Sampah Rumah Tangga dalam Upaya Pemilihan Teknologi Pengelolaan Sampah di Kota Denpasar. Tesis Program Pasca Sarjana Universitas Udayana.

Bappedes. 2017. Badan Perencanaan Pembangunan Desa Pakraman Ubud.

Diparda. 2006. Kumpulan Data Kepariwisataan Provinsi Bali. Dinas Pariwisata Daerah Provinsi Bali.

Harmini, A.A.A.Ngr.2005. Studi Manajemen Komunitas di Objek Wisata Wenara Wana, Padangtegal, Ubud Menuju Pariwisata Berkelanjutan. Tesis Program Pascasarjana Universitas Udayana
Neolaka, Amos. 2008. Kesadaran Lingkungan. Jakarta : Rineka Cipta.

Suarna, I Wayan. 2008. Model Penanggulangan Masalah Sampah Perkotaan dan Pedesaan. Denpasar : Pusat Penelitian Lingkungan Hidup Universitas Udayana.

Undang-Undang Nomor 32 Tahun 2009 Tentang Perlindungan danPengelolaan Lingkungan Hidup.

Tchobanoglous, G., Theisen, H., dan Vigil, S., (1993), Integrated Solid Waste Management, Mc.Graw Hill Inc, International Editions, New York.

Triyadi, Sugeng S dan Andi Harapan S. 2006. Tempat Sampah, Perilaku Manusia, dan Pembangunan Berkelanjutan. Jurnal Teknik Lingkungan. Edisi Khusus Agustus 2006.

Widyatmoko, MM. Sintorini Murdoko, 2002, Menghindari, Mengolah dan Menyingkirkan Sampah, Jakarta: Abdi Tandur 